\title{
ERRATUM
}

\section{Regaining Jerusalem: Eschatology and Slavery in Jewish Colonization in Seventeenth-Century Suriname-ERRATUM}

Natalie Zemon Davis

Doi:10.1017/pli.2015.29. Published by Cambridge University Press, December 11, 2015.

The caption of Figure 2 contains the incorrect year. It should read "(Amsterdam: Joan Blaeu, 1659)".

The author and publisher regret this error.

\section{Reference}

Natalie Zemon Davis. "Regaining Jerusalem: Eschatogy and Slavery in Jewish Colonization in Seventeenth-Century Suriname," The Cambridge Journal of Postcolonial Literary Inquiry 3 (2016): 11-38. 